\title{
International unions concerned about biodata
}

\author{
Action must be taken now to ensure that data are safely archived and always accessible.
}

Sir - The guaranteed and sustained public availability of primary, fundamental, experimental scientific data is a matter of considerableconcern. Such data include (but are not exclusiveto) nucleotide sequences of biological organisms, amino-acid sequences of proteins, threedimensional structures of biological molecules, and other data produced by genomics and proteomicsstudies.

In Correspondence (N ature 417, 222; 2002), D. Agosti and N. F. Johnson stress the importance of open access to taxonomic data, noting that the situation for basic taxonomic data is much worse than for genomic data. But even for genomic and structural data there are no internationally agreed mechanisms for ensuring continuing open access to data, and no strict rulesfor their deposition in public archival databases. These pressing issues have recently been considered by the Inter-Union BioinformaticsGroup (IUBG), which contains, under the umbrella of the International Council for Science(ICSU), representatives from several international unions: the International Union for Pure and Applied Biophysics, the International Union of Biochemistry and Molecular Biology, the International Union of Pureand Applied Chemistry, the International Union of Crystallography and the ICSU Committee on Data for Science and Technology. The
IU BG report of M ay 2002 is availableat http://md.chem.rug.nl/ berends/IUBGFinal Report.html or via www.IUPAB.org. In the fields of genomics, proteomics and macromolecular structures, the primary scientific data, which form an essential part of a scientific publication, are not included in detail in publications, but are deposited in databases. It has always been the practice that those who claim scientific advances in their published work support their claim by making the objective data on which their claim is based openly available. Therefore, such data must be available on at least the same basis as the publication itself, if the common standards of scientific integrity are to be maintained.

The databases concerned are at present maintained by institutions that do not have the support status of national libraries. It is not yet generally recognized at government level that thearchiving of such data needs protection similar to thearchiving of literature; the responsibilities to maintain the collections and safeguard their integrity and access into the distant future are not clearly defined and internationally agreed.

TheIUBG report contains four explicit statements and seven recommendations. It recommends: first, that the international scientific unionsidentify key archival databases and havean active role in standardization; second, that publishers require authors to deposit their primary data in a key archival database; third, that funding agenciesinsist on such deposition and actively support primary-data repositories; and fourth, that legislators ensurethat laws on intellectual property rights allow thefair use of data for scientific and educational purposes.

The aim of theIUBG report isto stir up thescientific community worldwide. TheU S government hastaken thelead by supporting GenBank and the Protein D ata Bank, but the maintenance of archival databases is a supranational activity. At present thereare different models for funding various databases and there are different funding modelsin theUnited States, Europeand Japan. Nonehas an explicit long-term commitment. The obligation to deposit data must be followed worldwide. There must bea singleinternational archive for each class of data, even if it is distributed over more than onesite, and data must remain uniform in format. Thereis an urgent need for international agreements to stabilize thesituation and to guarantee cooperation, consistency and funding. Jean Garnier*, Herman J. C. Berendsent *IN RA Centre de Recherche deVersailles, Unitéde $M$ athematique, Informatiqueet Genome, RD 10 (routedeSaint-Cyr), 78026 Versailles Cedex, France †D epartment of Chemistry, the University of Groningen, Nijenborgh 4, 9747 AG Groningen, TheN etherlands

\section{Feeding the world}

Sir - Your "Food and the Future" Insight ${ }^{1}$ discusses problems of and prospects for agriculture. In the overview article, Anthony Trewavas (pages 668- 670 of ref. 1) argues that agricultural technologies have averted and will continue to avert malthusian crises in which the human population exceeds its food supply. Trewavas writes: "The lessons of history areclear. Successivelurchesin population number havedriven the development of new agricultural technologies designed to providefood for growing populations."

Thereare, however, other perspectives. An alternativeanalysis ${ }^{2}$ shows that the development of new agricultural technologies has been driven by increasing corporatization and economicintegration of agricultural processes and products, particularly in thetwentieth century when the most spectacular increase in human population sizeoccurred. During this time, famine resulted not from a global or even (according to some perspectives) local shortage of food ${ }^{3-5}$, but from poverty and lack of political power among starving people.

Trewavas discusses concernsabout how the projected ninebillion peoplethat will inhabit the Earth later this century will befed. Even today'sfood supply would suffice if cultural preferences could bechanged to reduce meat consumption substantially. This change could, in principle, free more than $40 \%$ of the world's grain to feed peoplerather than livestock ${ }^{6}$. But feeding people receives a lower priority in thecurrent food system than does the profit to be made from the global spread of luxury diets - most of which have deleterious effects on both human and ecosystem health?

Werequire agricultural practices that are morehospitable to nativebiodiversity than are the industrial methods that prevail today ${ }^{8}$. Thethreechallenges of agricultureare: to feed everyonewell; to safeguard biodiversity; and to providea decent living for those who producefood. Thesegoals are neither incompatible nor imaginary. From urban gardensin Cuba, to shade-coffeefarms in M exico, to grassfed beef from $M$ innesota, to communitysupported agriculture supplying food to downtown N ew Yorkers - some ecologically and economically innovative farmers and consumers are attempting to reshape thefood system to emphasize sustainability over production.

\section{CatherineBadgley}

M useum of Paleontology, 1109 Geddes Road,

University of Michigan, Ann Arbor,

Michigan 48109-1079, USA

1. Nature418,667-707 (2002).

2. Goodman, D., Sorj, B. \& Wilkinson, J. From Farming to Biotechnology: A Theory of Agro-Industrial D evelopment (Blackwell, Oxford, 1987).

3. Sen, A. Resources, Values, and Development (Blackwell, Oxford, 1984).

4. Drieze, J. \& Sen, A. (eds) The Political Economy of Hunger (Clarendon, Oxford, 1990).

5. Lappé, F. M., Collins, J. \& Rosset, P. World Hunger: Twelve Myths (Grove, New York, 1998).

6. Smil, V. FeedingtheWorld (MIT Press, Cambridge, Massachusetts, 2000).

7. Gardner, G. \& Halweil, B. in State of theWorld 2000 (eds Brown, L. R. et al.) 59-78 (Norton, New York, 2000).

8. Daily, G. C. in Natureand Human Society (ed. Raven, P.) 104-113 (Nat. Acad. Press, Washington DC, 1997). 